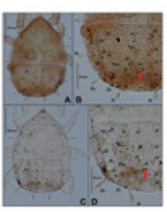

\title{
Redescription of Suctarsonemus litteratus (Mahunka, 1973) (Prostigmata: Tarsonemidae)
}

\author{
José M. Rezende, Antonio C. Lofego \& Ronald Ochoa
}

To cite this article: José M. Rezende, Antonio C. Lofego \& Ronald Ochoa (2017) Redescription of Suctarsonemus litteratus (Mahunka, 1973) (Prostigmata: Tarsonemidae), International Journal of Acarology, 43:8, 582-593, DOI: 10.1080/01647954.2017.1373856

To link to this article: https://doi.org/10.1080/01647954.2017.1373856

册 Published online: 08 Sep 2017.

Submit your article to this journal $\pi$

Џ Article views: 40

View Crossmark data \lceil 


\title{
Redescription of Suctarsonemus litteratus (Mahunka, 1973) (Prostigmata: Tarsonemidae)
}

\author{
José M. Rezende (1) ${ }^{\mathrm{a}, \mathrm{b}}$, Antonio C. Lofego (1) a and Ronald Ochoa ${ }^{\mathrm{c}}$
}

aDepartment of Zoology and Botany, São Paulo State University (Unesp), Institute of Biosciences, Humanities and Exact Sciences (Ibilce), São

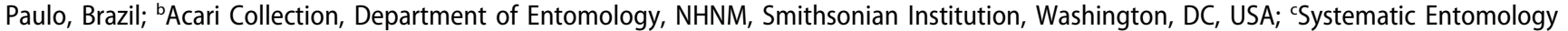
Laboratory, United States Department of Agriculture, Agricultural Research Service, Beltsville, MD, USA

\section{ABSTRACT}

A redescription of Suctarsonemus litteratus (Mahunka) with new line drawings, micrographs, and measurements is provided. In addition, a key to separate the species of the genus Suctarsonemus is presented.
ARTICLE HISTORY

Received 31 May 2017 Accepted 24 August 2017

Published online 8 September 2017

\section{KEYWORDS}

Acari; diversity; Heterostigmatina; mite; fauna; taxonomy

\section{Introduction}

Suctarsonemus is an uncommon tarsonemid genus, which has been recorded only from the Afrotropical zoogeographical region (Mahunka 1973a, 1973b, 1974; Lin and Zhang 2002). The genus has been collected from light trap residues, which may suggest an association to insects (Lindquist 1986). Much of its biology is unknown. Only adult females have been described; nothing is known of the adult males or immature forms. Mahunka (1974) described the genus based on specimens of Suctarsonemus striatissimus from Ghana. Later, Lindquist (1986) redescribed the genus and transferred two more species, Suctarsonemus litteratus (Mahunka) and Suctarsonemus xystoforus (Mahunka) from Tarsonemus. Currently, these three species are the only known representatives in the genus.

Due to the technology available at that time, Mahunka (1973a) described S. litteratus using few characters and simple drawings. As part of an effort to improve our knowledge of the family Tarsonemidae and its phylogenetic relationships, Suctarsonemus litteratus is redescribed and illustrated herein.

\section{Material and methods}

The holotype of Suctarsonemus litteratus was loaned from the Hungarian Natural History Museum, Arachnoidea Collection, Budapest, Hungary (slide code HNHM Heter-5048). It was analysed using two microscopy techniques: phase-contrast and differential interference contrast (DIC). The terminology used herein mainly follows that of Lindquist (1986), except for gnathosomal setae $d g$ s and vgs (Suski 1967; Magowski et al. 1998). For each structure, the mean measurements are provided in micrometres $(\mu \mathrm{m})$. The specimen was drawn and photographed using Leica DM 2500 and Leica DFC 500 microscopes, respectively.

\section{Results}

Family Tarsonemidae Canestrini and Fanzago, 1877

Genus Suctarsonemus Mahunka, 1974

Suctarsonemus litteratus (Mahunka, 1973)

\section{Diagnosis}

Suctarsonemus litteratus is most similar to Suctarsonemus xystoforus (Mahunka) by the identical length of dorsal setae $c 1, d, e_{t}$ and $f$; and conspicuous shape of the sejugal apodeme along its whole extension. They can be distinguished by the shorter length of its dorsal setae $s c 2, c 2$ anf $h$ ( $\pm 30,20$, and $20 \mu \mathrm{m}$, respectively) in comparison with those of $S$. xystoforus $( \pm 60,30$, and $50 \mu \mathrm{m}$, respectively).

\section{Adult female (holotype measured). \\ Figures 1-7.}

Gnathosoma. Subquadrate in ventral view, length 35, maximum width 26; palps 10, each as long as it basal width, with small palptarsal processes and two minute setae on each palp; pharynx fusiform, 15 long, $0.3 \times$ the length of gnathosoma, 9 wide at maximum width, and $0.3 \times$ the maximum width of gnathosoma. Cheliceral stylets difficult to discern, short, thin, and attached to inconspicuous basal levers. Setae $d g s \mathbf{1 5}$, setiform and serrate. Setae vgs 9, setiform and smooth. Setae $p p$ absent or not visible. Relative length of gnathosomal setae (dgs: $v g s)$ : 1: 0.6 .

Idiosoma - dorsum (Figure 1). 225 long; 138 wide at level of $c 2$, all dorsal plates with punctate sculpturing. Prodorsal shield 100 long and $\mathbf{1 1 4}$ wide at level of stigmata, hoodlike and entirely covering the gnathosoma. Stigmata openings at level nearly anteriad of scapular setae scl and located on inconspicuous projections from shallow emarginations of lateral margins. Tracheae without visible atria; postatrial sacs absent or not visible. Tergite C $\mathbf{7 5}$ long and $\mathbf{1 3 8}$ wide at level of $c 2$ and striate on its lateral margins. Tergite $D \mathbf{4 0}$ long and $\mathbf{1 2 7}$ wide at level of $d$. Tergite EF 12 long and $\mathbf{9 0}$ wide at level of the $e$ setae. Tergite $\mathrm{H}$ 12 long and $\mathbf{5 0}$ wide at level of $h$ and with a deep emargination at the middle of posterior margin.

Idiosomal dorsal setae (Figures 1 and 4). v1 22, setiform, smooth; sc1 17, capitate, with tiny spines; sc2 36, setiform, smooth, inserted posterior to sc1; $c 1$ 16, setiform and smooth, located near the marginof tergite $D ; c 2$ 20, setiform and smooth; $d$ 18, setiform and smooth; $e$ 13, setiform and serrate; $f \mathbf{1 6}$, setiform and smooth; $h \mathbf{1 7}$, setiform and serrate. Relative length of dorsal setae (v1: sc1: sc2: $c 2$ : $c 1$ : $d:$ e: $f: h$ ): 1: 0.8: 1.6: 0.7: 0.9: 0.8:

CONTACT José M. Rezende jmrezende@live.com ĐDepartment of Zoology and Botany, São Paulo State University (Unesp), Institute of Biosciences, Humanities and Exact Sciences (Ibilce), Campus São José do Rio Preto, São Paulo 15054-000, Brazil

(c) 2017 Informa UK Limited, trading as Taylor \& Francis Group 


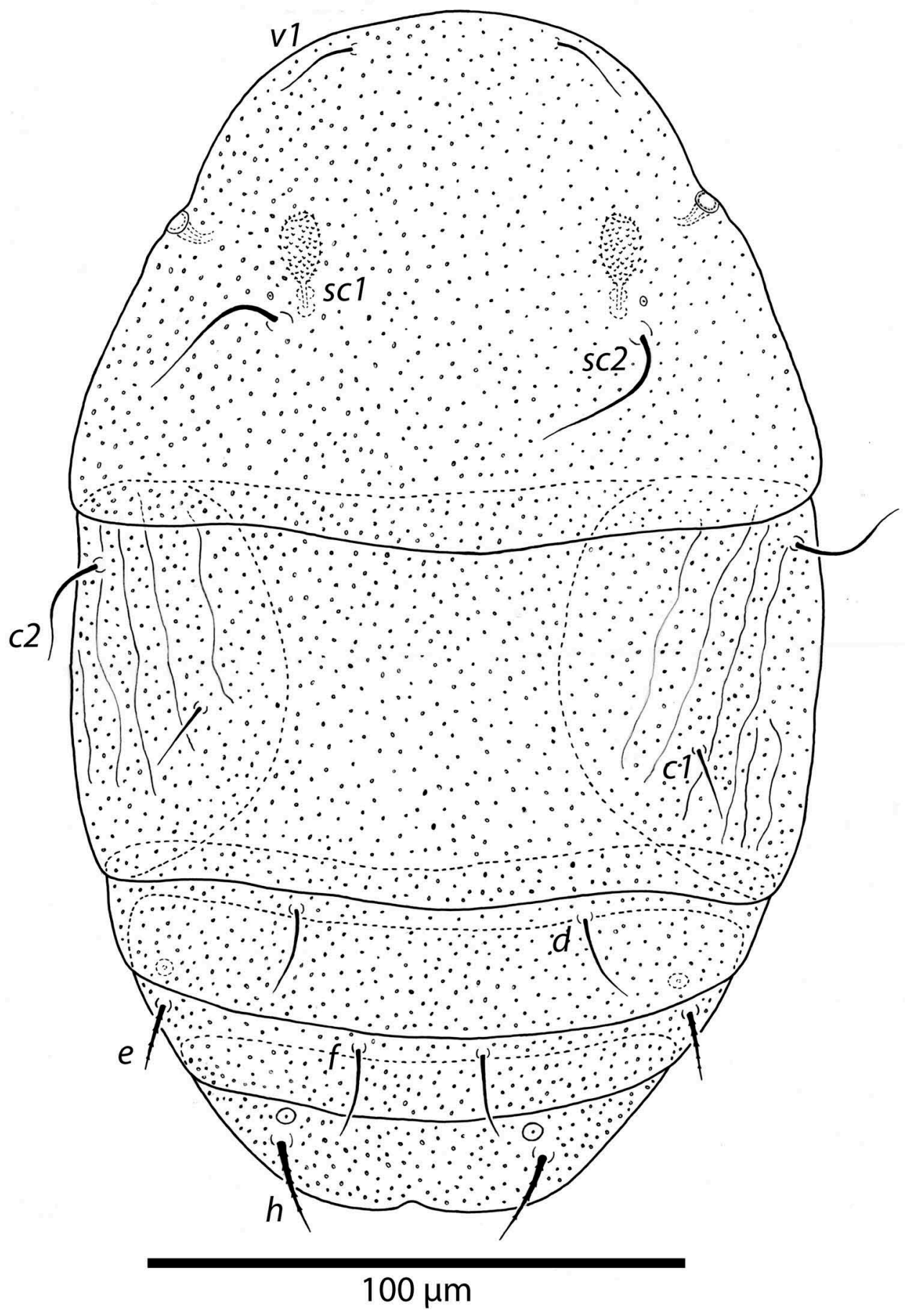

Figure 1. Suctarsonemus litteratus: dorsal surface of the idiosoma.

0.6: 0.7: 0.8. Distance between dorsal setae: $v 1-v 141$; sc1-sc1 45; $s c 2-s c 2$ 67; v1-sc2 57; $c 1-c 1$ 90; $c 2-c 2$ 130; $c 1-c 2$ 50; $d-d$ 55; $f-f$ 22; $e-f$ 40; $h-h$ 50. Relative distance of dorsal setae bases ( $v 1-v 1$ : sc1-sc1: sc2-sc2: v1-sc2: c1-c1: c2-c2: c1-c2: $d$-d: e-e: f-f: e-f: h-h): 1: 1.1: 1.4: 1.4: 2.3: 3.2: 1.2: 1.3: 2.1: 0.5: 1: 1.2. Pits of $v 2$ located about half way between bases of setae sc1 and sc2. Diameter and position of cupules: ia difficult to discern; im $\mathbf{3}$ anterad of setae $e ;$ ih $\mathbf{3}$ anterad of setae $h$.

Idiosoma - venter (Figures 2, 5 and 7). Setae 1a 12, setiform and smooth; $2 a$ 17, setiform and smooth; $3 a 17$, setiform, smooth and located near anteriomedial margins of apodemes $3 ; 3 b \mathbf{1 8}$, setiform, smooth and located on the posterior margin of apodemes 4; $p$ s 12, setiform and smooth. Relative length of ventral setae (1a: 2a: 3a: 3b: ps): 1: 1.4: 1.4: 1.5: 1. Coxal pits: $1 b$ located well laterad of setae $1 a ; 2 b$ located well laterad of setae $2 a$. Apodeme 1 conspicuous, fused to anterior end of prosternal apodeme.
Apodeme 2 short, not fused to prosternal apodeme. Prosternal apodeme conspicuous, extending from junction with apodeme 1 to sejugal apodeme. Sejugal apodeme uninterrupted, with a single median indentation. Apodeme 3 extending diagonally from proximity of base of seta $3 a$ to anterior margin of trochanter III, with a median bent. Apodeme 4 extending diagonally, from the anterior third of the poststernal apodeme to base of seta $3 b$. Poststernal apodeme bifurcated anteriorly. Tegula 6 long, 16 wide; posterior margin slightly arched.

Legs (Figures 3 and 6). Total length (measured from femur to tarsus): leg I 58, femur I with a small flange, tibiotarsus I thick with distal margin rounded; leg II 61, femur II with a small flange, difficult to discern, leg III 96; leg IV 47, femorogenu IV 34, tibiotarsus IV 13. Number of setae (solenidia in parentheses) on femur, genu, tibia and tarsus, respectively: leg I: 4-4-6(2)+8(1); leg II: 3-3-4-6(1); leg III: $1+3-4-5$; leg IV:1 + 1-1 + 1. Setae present 


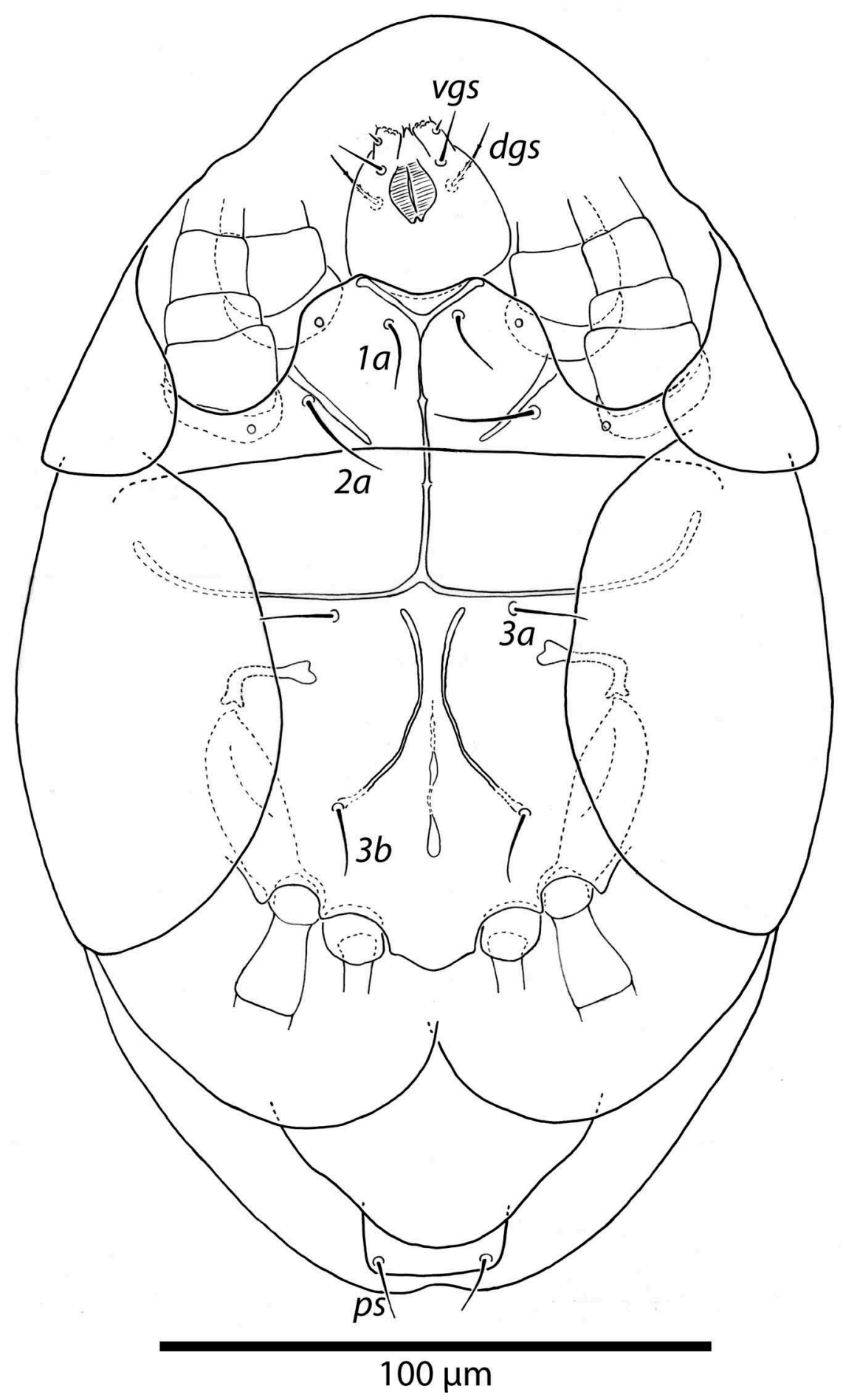

Figure 2. Suctarsonemus litteratus: ventral surface of the idiosoma.

on each leg segment: Leg I: femur I: $d \mathbf{5}$ serrate, l' 8 serrate, l" 4 serrate, $v^{\prime \prime} \mathbf{2 3}$ serrate; genu I: l' $\mathbf{1 7}$ serrate, l' $\mathbf{1 8}$ serrate, $v^{\prime} \mathbf{8}$ serrate, $v^{\prime \prime} 15$ serrate; tibiotarsus I: (setae): $d 28$ serrate, $l^{\prime} \mathbf{1 7}$ serrate, l" 19 serrate, $v^{\prime} 21$ serrate, $v^{\prime \prime} 16$ serrate, $p v^{\prime} 10$ serrate, $p v^{\prime \prime} 12$ serrate, $p l^{\prime} 13$ serrate, $u^{\prime \prime} \mathbf{2}$ thick (euphatidia): $p^{\prime \prime}$ 25, $p^{\prime \prime}$ 21, $t c^{\prime} \mathbf{2 0}, t c^{\prime \prime} 21$ (solenidia): tips striated; sensory cluster of tibiotarsus I complete, with all setae inserted at approximately the same level: solenidion $\phi 13$ slender and capitate, solenidion $\phi 23$ fusiform and stout; solenidion $\omega \mathbf{1 0}$, stout and wider medially (famulus): $k$ 5. Leg II: femur II: $d \mathbf{6}$ smooth, $l^{\prime} \mathbf{1 0}$ serrate, $v^{\prime \prime} \mathbf{2 2}$ serrate; genu II: I' 17 serrate, l" 8 leaf-shaped serrate, $v^{\prime} 11$ serrate; tibia II: d $\mathbf{2 5}$ serrate, I" $\mathbf{2 2}$ serrate, $v^{\prime \prime} \mathbf{2 0}$ serrate, $v^{\prime \prime} \mathbf{2 3}$ serrate; tarsus II: $t c^{\prime}$ 18 serrate, $t c^{\prime \prime} 20$ serrate, $p v^{\prime} 17$ serrate, $p v^{\prime \prime} 12$ serrate, $p l^{\prime \prime} 5$ spinelike and thick, $u^{\prime \prime} \mathbf{3}$ thick, solenidion $\omega \mathbf{1 0}$ proximally inserted, stout, wider medially. Leg III: femorogenu III: $v^{\prime \prime} \mathrm{F} 15$ serrate, $v^{\prime \prime}$ G 20 serrate, $l^{\prime \prime} 10$ serrate, I" 12 serrate; tibia III: $d \mathbf{3 2}$ serrate, I" $\mathbf{3 0}$ serrate, $v^{\prime \prime} \mathbf{1 5}$ serrate, $v^{\prime \prime} \mathbf{1 7}$ serrate; tarsus III: tc' 10 smooth, $t c^{\prime \prime} 23$ serrate, $p v^{\prime} 15$ serrate, $p v^{\prime \prime} 20$ serrate. Leg IV: femorogenu IV: $v^{\prime \prime}$ F 15 smooth, $v^{\prime \prime}$ G 23 smooth; tibiotarsus IV: $v^{\prime}$ Ti 43 falcate, $t c^{\prime \prime} 65$ smooth. Ambulacra of legs I-III: ambulacrum I with a well-developed membranous structure bearing one long slender claw, which is sharply curved basally; ambulacra II and III with normally developed empodium and two symmetrically paired claws.

Key to the species of the genus Suctarsonemus (Acari: Tarsonemidae) (based only on adult females and drawings of Mahunka 1973a, 1973b, 1974; Lindquist 1986):

1. Setae $c 1, d, e$, and f long $( \pm 50,60,70$, and $60 \mu \mathrm{m}$, respectively); sejugal apodeme inconspicuous on its median portion S. striatissimus (Figures 8 and 9) 


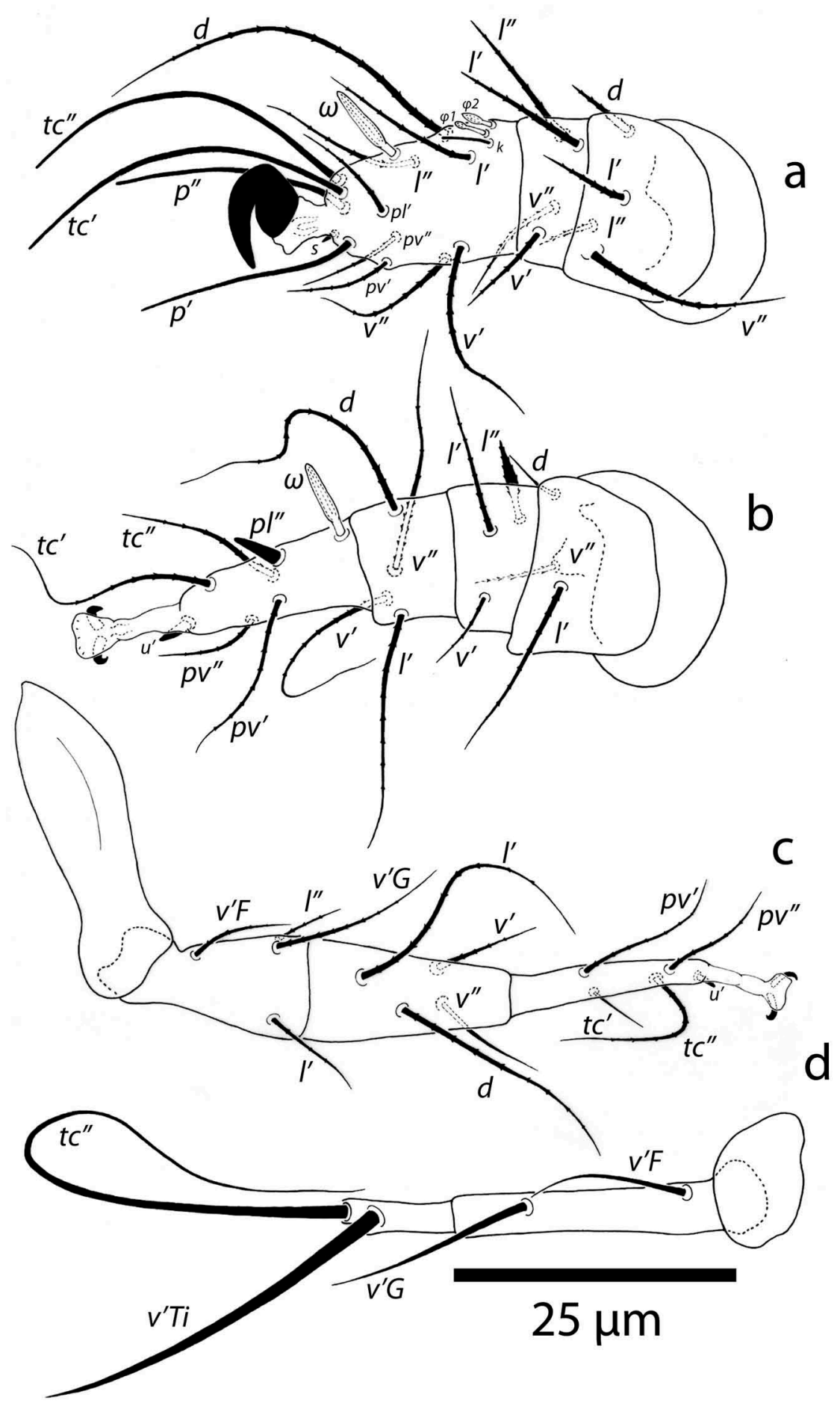

Figure 3. Suctarsonemus litteratus: Legs - leg I (right side and ventral aspect); B - leg II (right side and dorsal aspect); C - leg III (left side and dorsal aspect); D - leg IV (right side and ventral aspect).

Setae $c 1, d, e$, and $f$ short $( \pm 25,25,20$, and $25 \mu \mathrm{m}$, respectively); sejugal apodeme conspicuous on its median portion

2

2. Setae $s c 2, c 2$, and $\mathrm{h}$ long $( \pm 60,30$, and $50 \mu \mathrm{m}$, respectively)... S. xystoforus (Figures 10 and 11)

Setae $s c 2, c 2$, and $h$ short $( \pm 30,20$, and $20 \mu \mathrm{m}$, respectively)... S. litteratus (Figures 1-7)

\section{Discussion}

Species identification and descriptions of their morphological characters have improved over the years due to use of new or improved technology, e.g. DIC microscopy and low-temperature scanning electron microscopy (Rezende et al. 2015). This redescription of S. litteratus using more modern techniques and the addition of micrographs improve our ability to identify and discover new characteristics of mites. Also, the more detailed line drawings and measurements of the dorsum, venter, legs, and setae allow us to better characterize and recognize the species. Suctarsonemus remains as a well-defined genus and a reliable source of information for future taxonomic and phylogenetic studies.

This genus is a fascinating member of Tarsonemini and located in a branch entirely associated with insects within this tribe. The association with insects has been suggested as a symplesiomorphic character for the entire family. In fact, members 


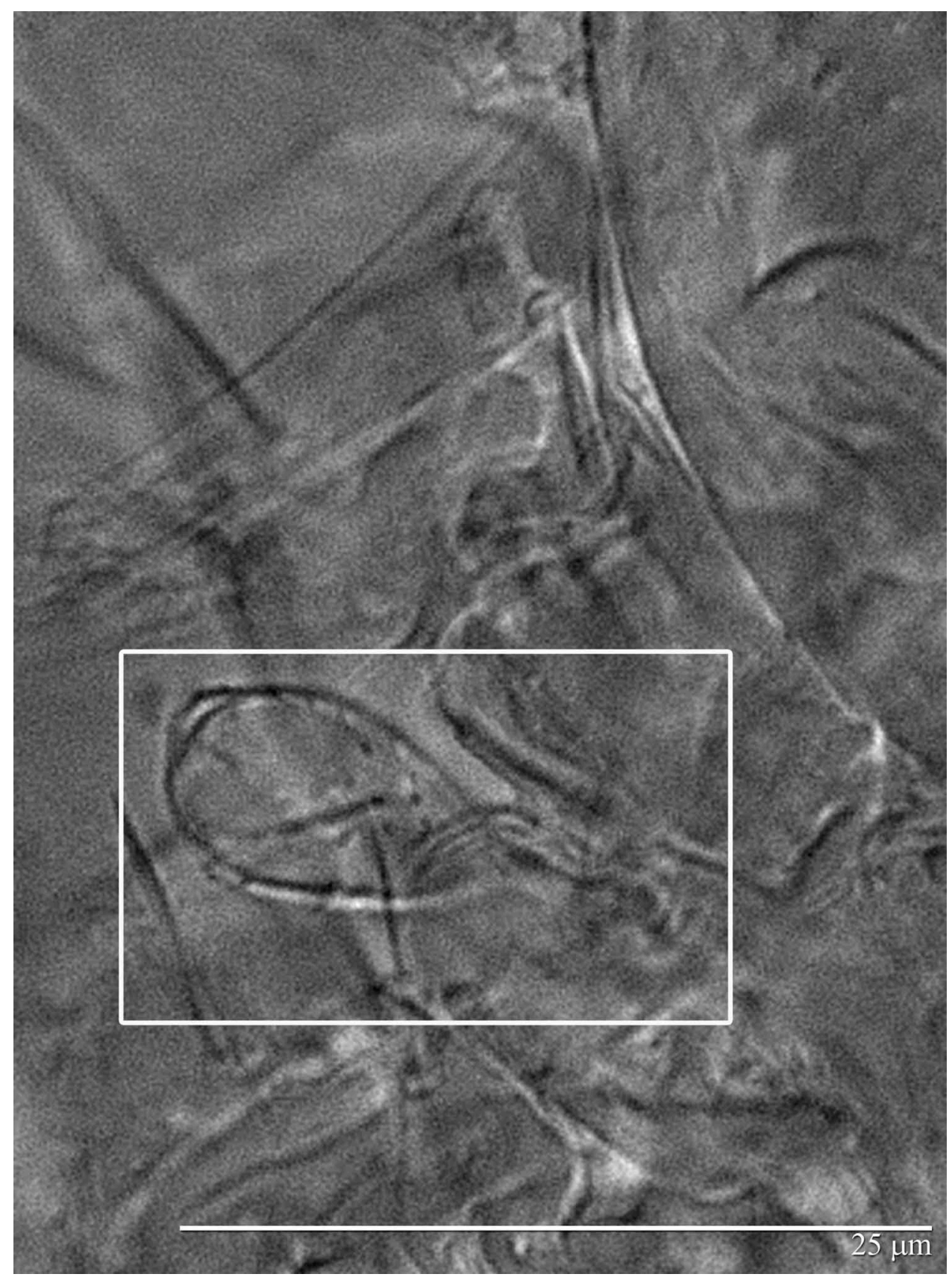

Figure 4. Suctarsonemus litteratus: detail of the bothridial seta sc1. 


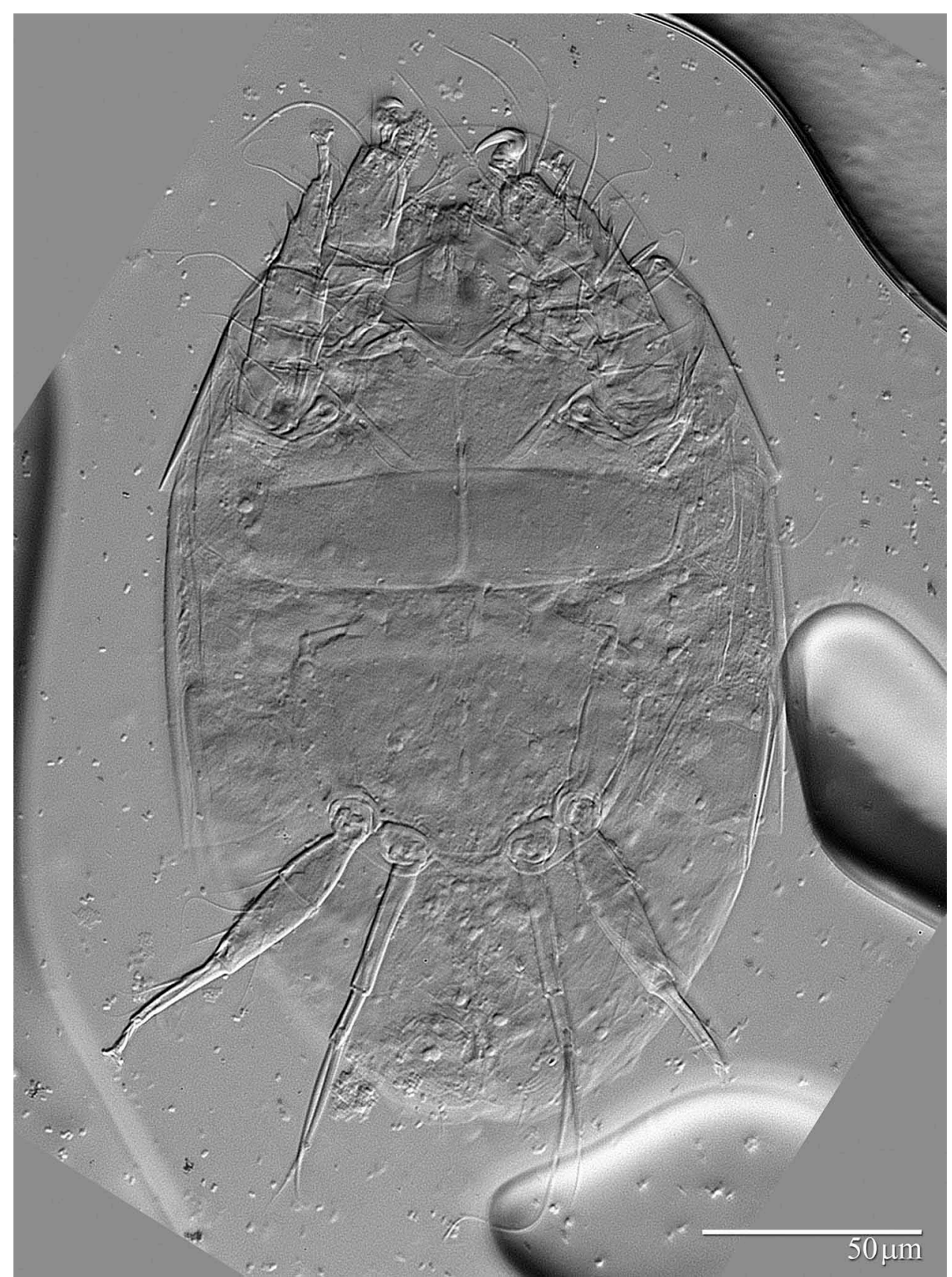

Figure 5. Suctarsonemus litteratus: ventral micrograph of the idiosoma. 


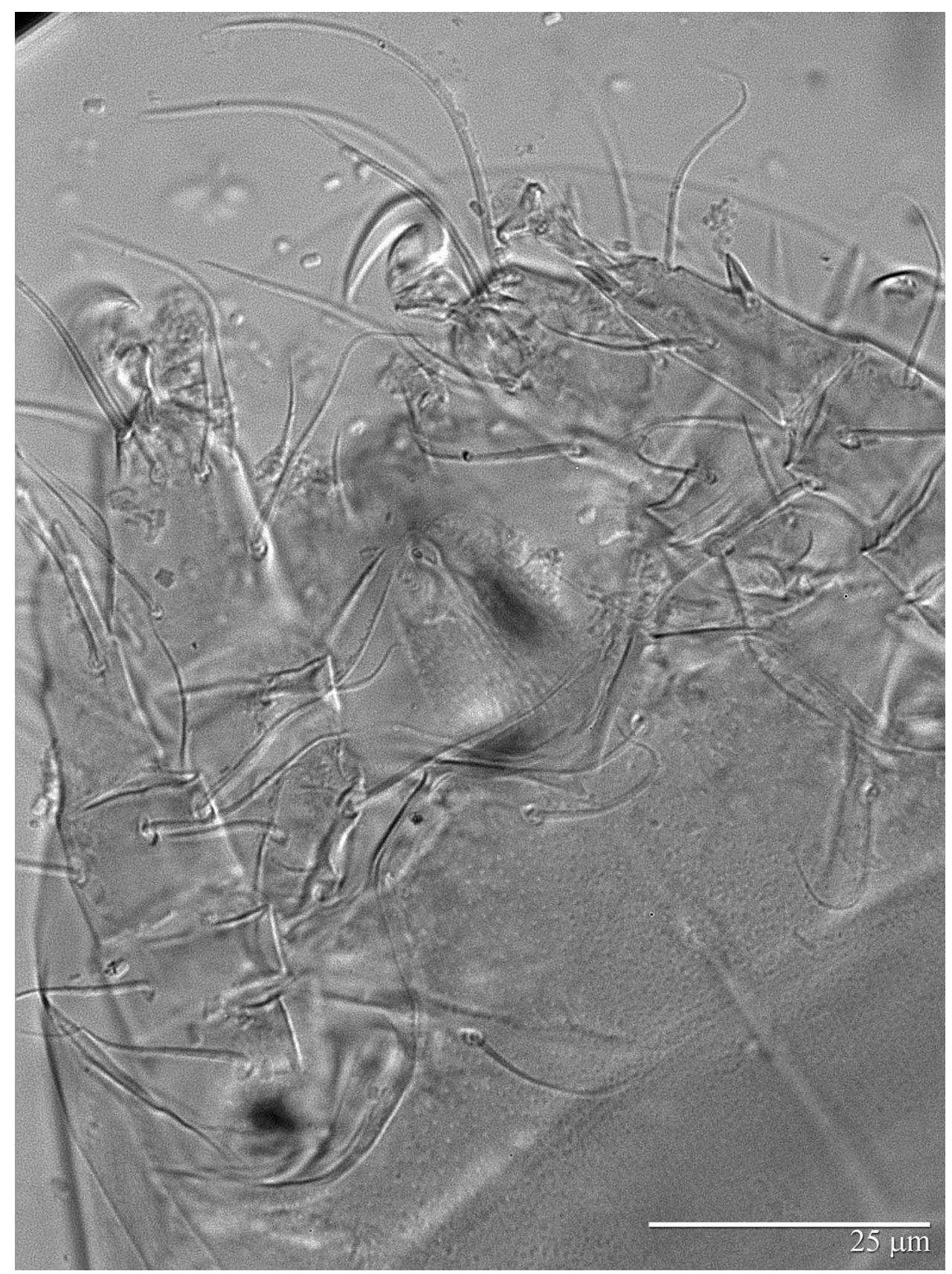

Figure 6. Suctarsonemus litteratus: ventral micrograph, with details of the gnathosoma and legs I and II. 


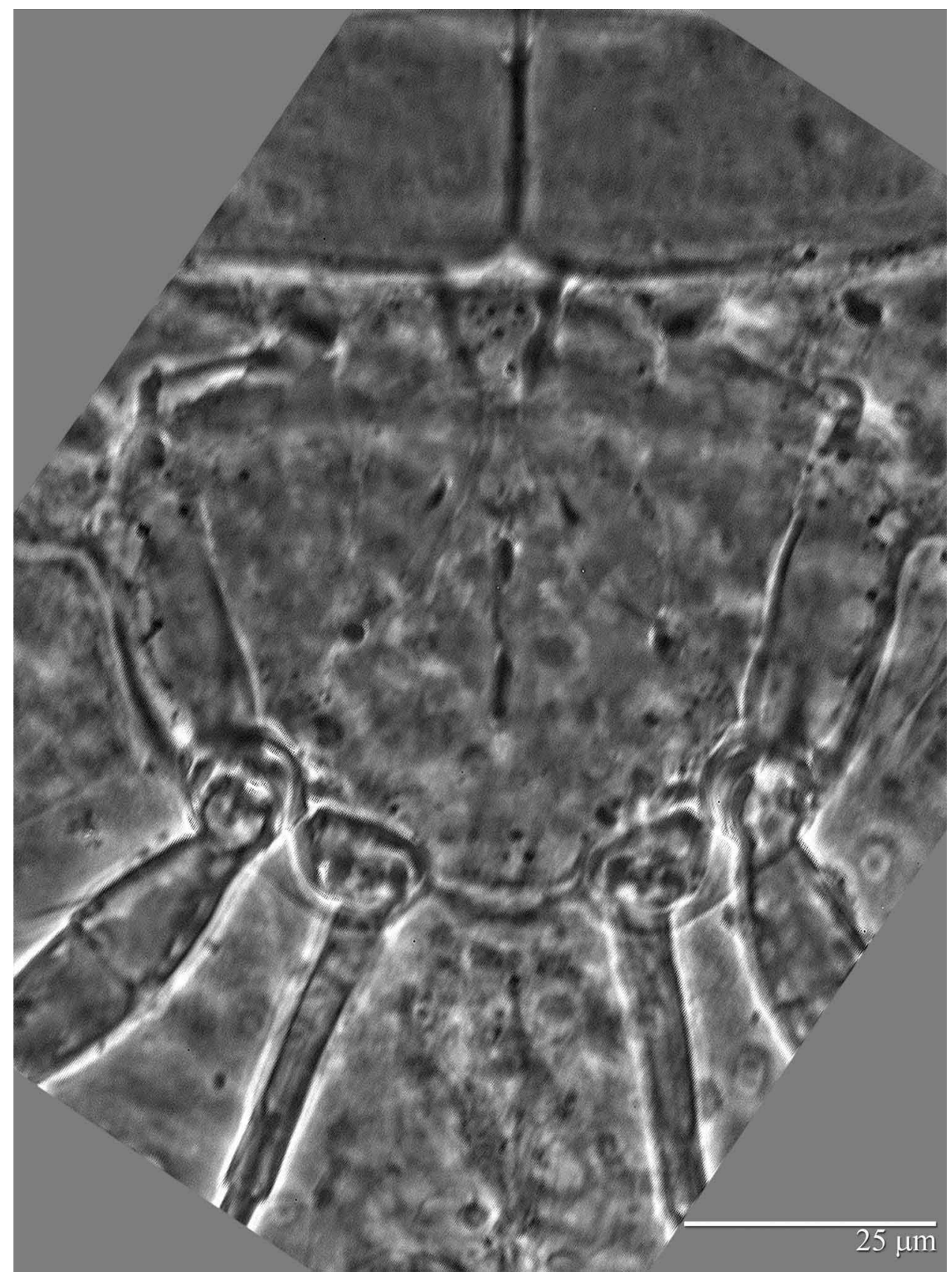

Figure 7. Suctarsonemus litteratus: detail of the poststernal apodeme. 


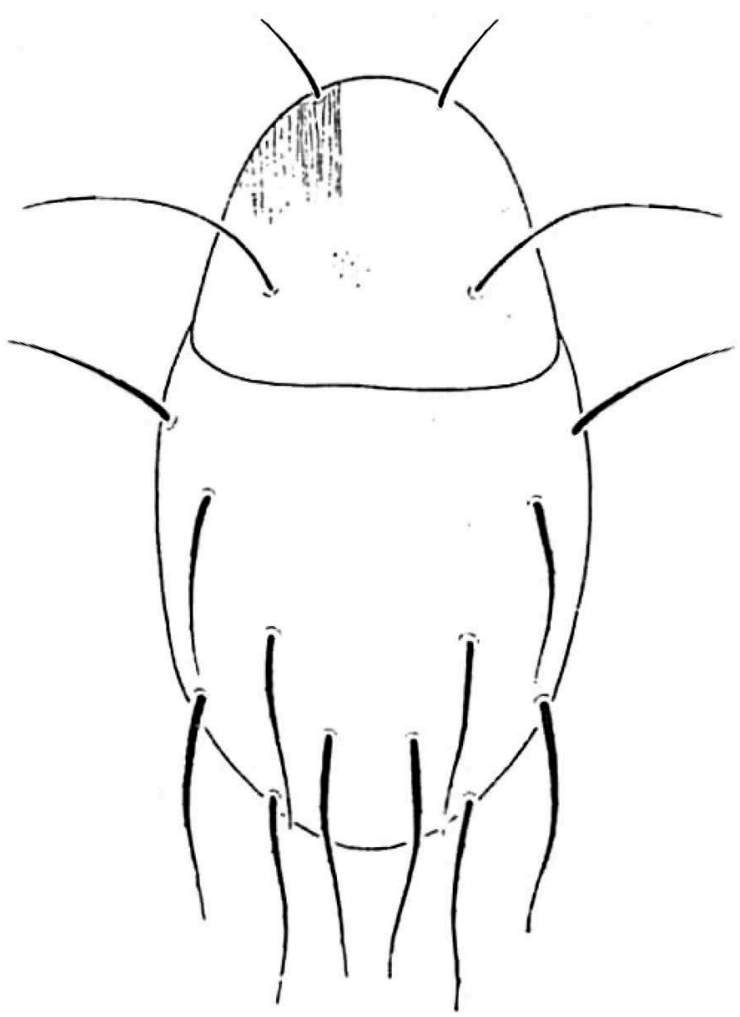

Figure 8. Suctarsonemus striatissimus: dorsal surface of the idiosoma (after Mahunka 1974, used with permission).

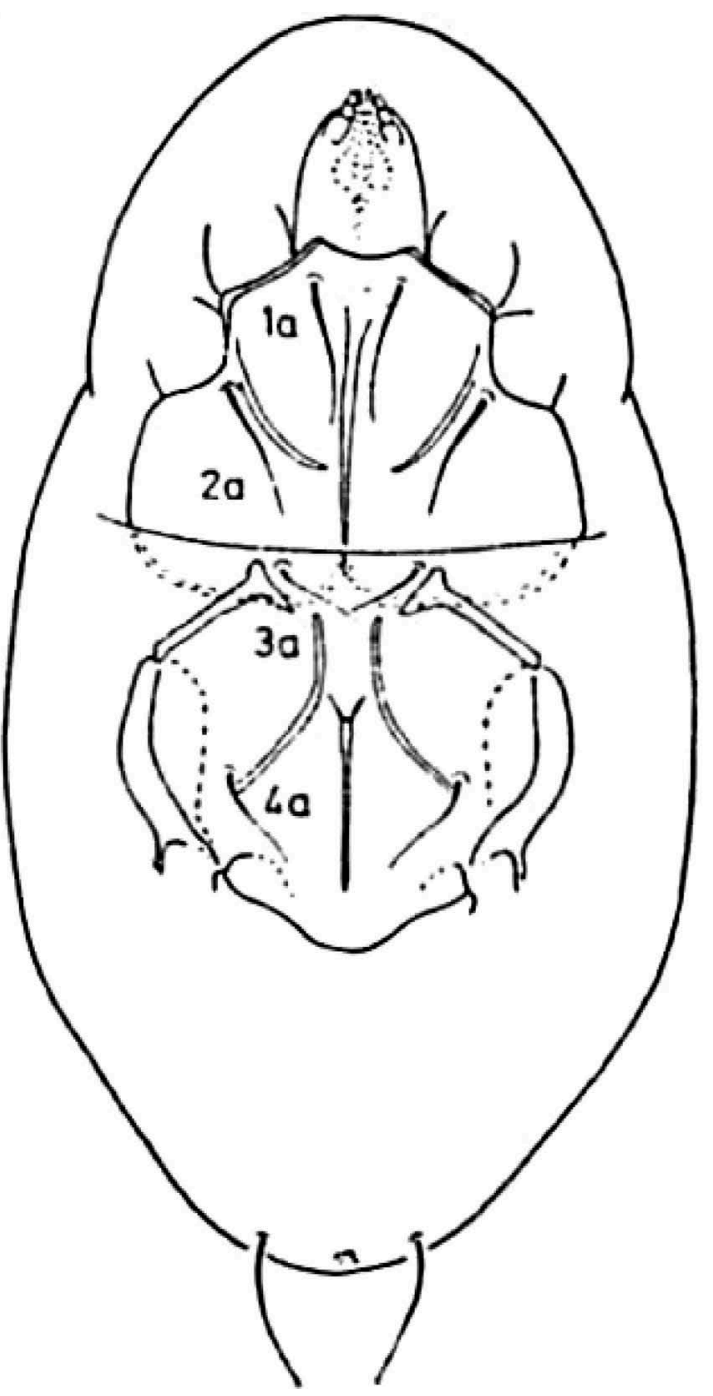

Figure 9. Suctarsonemus striatissimus: ventral surface of the idiosoma (after Mahunka 1974, used with permission). 


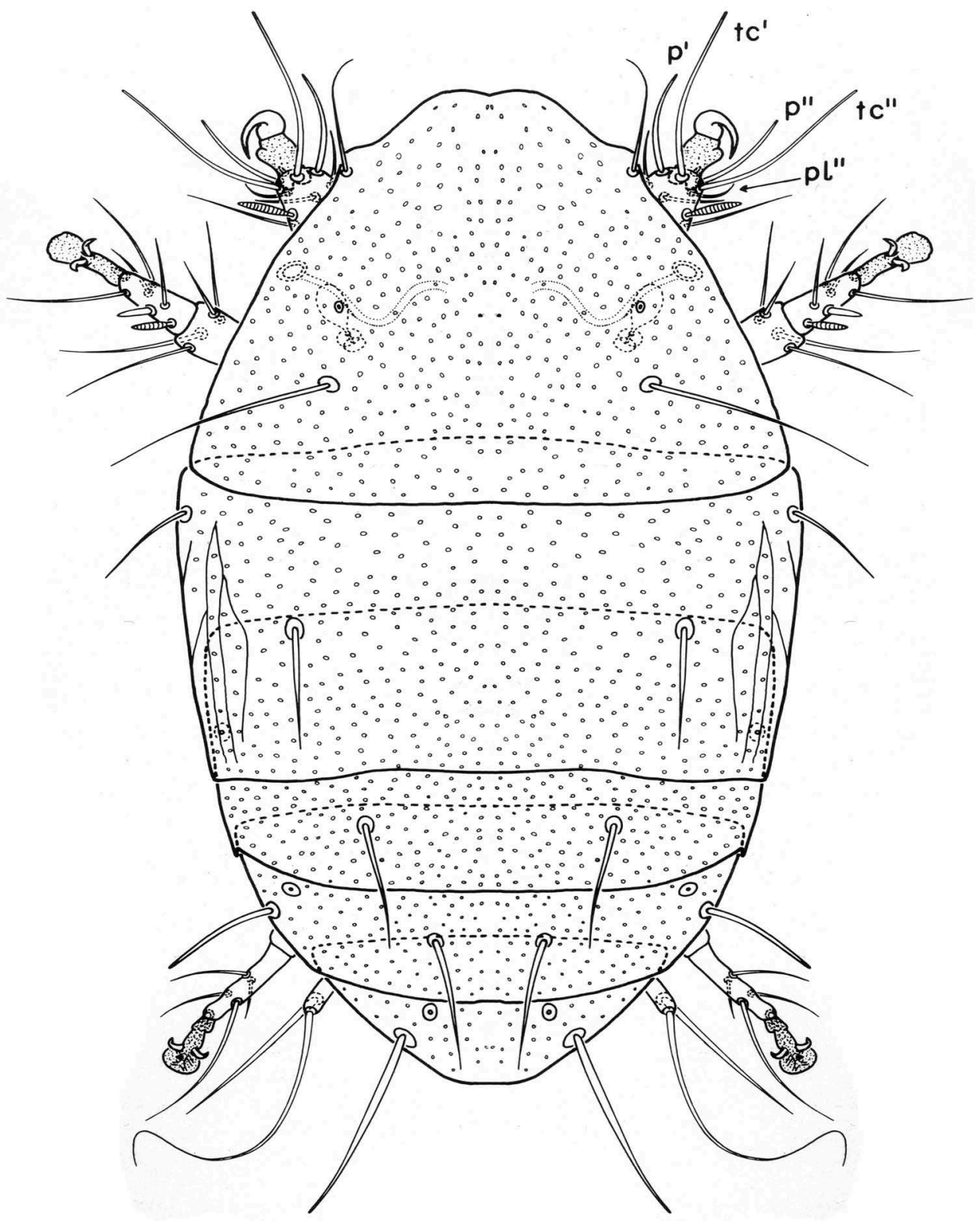

Figure 10. Suctarsonemus xystoforus: dorsal surface of the idiosoma (after Lindquist 1986, used with permission). 


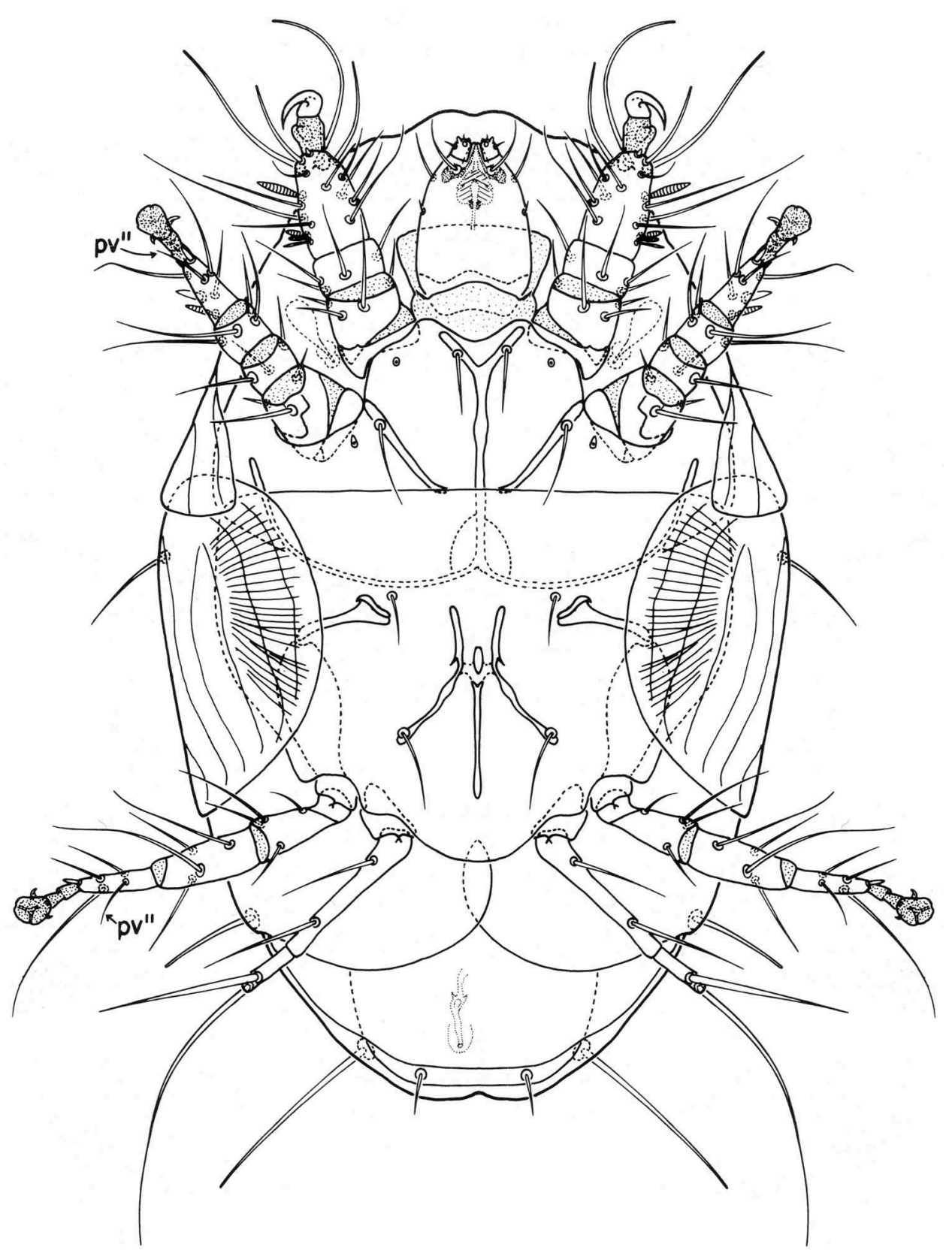

Figure 11. Suctarsonemus xystoforus: ventral surface of the idiosoma (after Lindquist 1986, used with permission). 
from all three of the tarsonemid subfamilies have been recorded from insects, especially in association with beetles (Lindquist 1986). Nevertheless, number of insect-inhabiting tarsonemids is considerably small in comparison with that of the plant-inhabiting species (Lin and Zhang 2002). More surveys of mites associated to insects throughout the world are needed to better understand the fauna and diversity of this and other genera of tarsonemids.

\section{Acknowledgments}

To FAPESP (Fundação de Amparo à Pesquisa do Estado de São Paulo) (Procs. 2015/19867-0 and 2016/16779-5) for the financial support. A.C. Lofego is a CNPq researcher (Proc. nr. 304562/2015-7). Special thanks to Dr László Dányi (HNHM Budapest, Hungary) for his help on finding and loaning the S. litteratus holotype, and to Dr Evert E. Lindquist (CNC-AC) for the information and comments on the genus Suctarsonemus, and also for authorizing the reproduction of figures from his monograph. To Dr Carlos H. W. Flechtmann (ESALQ-USP, Piracicaba, Brazil) for his help with the translation of $\mathrm{Dr}$ Sándor Mahunka's papers from German. Special thanks $t \mathrm{Dr}$ Gabor Bakonyi, Editor-in-Chief of the Acta Zoologica Academiae Scientiarum Hungaricae, for authorizing the use of the figures published on Mahunka (1974). Special thanks to $\mathrm{Dr}$ Gregory Evans (APHIS-USDA) and Andrew Ulsamer (USDA-ARS) for the review and the comments, and to Chris Pooley (ECMU-USDA) for his help with the drawings and micrographs. To the São Paulo State University (IBILCEUNESP), Smithsonian Natural History Museum (USNM), National Agricultural Library (NAL-USDA), and the Systematic Entomology Laboratory (SEL-USDA), for the support and assistance with references for this study. Mention of trade names or commercial products in this publication is solely for the purpose of providing specific information and does not imply recommendation or endorsement by the USDA; USDA is an equal opportunity provider and employer.

\section{Disclosure statement}

No potential conflict of interest was reported by the authors.

\section{Funding}

This work was supported by FAPESP (Fundação de Amparo à Pesquisa do Estado de São Paulo) (Procs. 2015/19867-0 and 2016/16779-5) for the financial support. A.C. Lofego is a CNPq researcher (Proc. nr. 304562/2015-7).

\section{ORCID}

José M. Rezende (D) http://orcid.org/0000-0001-7169-7456

Antonio C. Lofego (D) http://orcid.org/0000-0002-3495-6858

\section{References}

Lin J, Zhang ZQ. 2002. Tarsonemidae of the world: key to genera, geographical distribution, systematic catalogue \& annotated bibliography. London: Systematic and Applied Acarology Society. p. 440.

Lindquist EE. 1986. The world genera of Tarsonemidae (Acari: Heterostigmata): a morphological, phylogenetic and systematic revision, with classification of family-group taxa in the Heterostigmata. Ottawa: The Entomological Society of Canada. p. 517.

Magowski W, Di Palma A, Khaustov AA. 1998. Ununguitarsonemus rarus (Acari Tarsonemidae) a new species of mite associated with bark beetle from Crimea, Ukraine. Entomologica (Bari) 32:139-151.

Mahunka S. 1973a. Auf insekten lebende milben (Acari: Acarida, Tarsonemida) aus Afrika. I. Acta Zoologica Academiae Scientiarum Hungaricae 19:75-123.

Mahunka S. 1973b. Auf insekten lebende milben (Acari: Acarida, Tarsonemida) aus Afrika. II. Acta Zoologica Academiae Scientiarum Hungaricae 19:289-337.

Mahunka S. 1974. Auf insekten lebende milben (Acari: Acarida, Tarsonemida) aus Afrika. III. Acta Zoologica Academiae Scientiarum Hungaricae 20:137-154.

Rezende JM, Lofego AC, Ochoa R, Bauchan G. 2015. New species of Daidalotarsonemus and Excelsotarsonemus (Acari, Tarsonemidae) from the Brazilian rainforest. Zookeys 475:1-36.

Suski Z. 1967. Badania nad roztoczami z rodziny Tarsonemidae (Acarina, Heterostigmata) występującymi na jabłoniach w Polsce. Skierniewice: Institute of Pomology and Floriculture. p. 268. 